ARTICLE Prevalence, Serotype Diversity, Genotype and

\title{
Antibiotic Resistance of Listeria monocytogenes Isolated from Carcasses and Human in Korea
}

\author{
Hyemin $\mathrm{Oh}^{1,2}$, Sejeong $\mathrm{Kim}^{1,2}$, Soomin Lee ${ }^{1,2}$, Heeyoung Lee ${ }^{1,2}$, Jimyeong $\mathrm{Ha}^{1,2}$, \\ Jeeyeon Lee ${ }^{1,2}$, Yukyung Choi ${ }^{1,2}$, Kyoung-Hee Choi ${ }^{3, *}$, and Yohan Yoon ${ }^{1,2,{ }^{*}}$ \\ ${ }^{1}$ Department of Food and Nutrition, Sookmyung Women's University, Seoul 04310, \\ Korea \\ ${ }^{2}$ Risk Analysis Research Center, Sookmyung Women's University, Seoul 04310, Korea \\ ${ }^{3}$ Department of Oral Microbiology, College of Dentistry, Wonkwang University, Iksan \\ 54538, Korea
}

OPEN ACCESS

Received February 19, 2018

Revised May 29, 2018

Accepted June 3, 2018
*Corresponding author: Yohan Yoon Department of Food and Nutrition,

Sookmyung Women's University, Seoul 04310, Korea

Tel: +82-2-2077-7585

Fax: +82-2-710-9479

E-mail: yyoon@sookmyung.ac.kr

Kyoung-Hee Choi

Department of Oral Microbiology, College of Dentistry, Wonkwang University, Iksan

54538, Korea

Tel: +82-63-850-6911

Fax: +82-63-850-6911

E-mail: kheechoi@wku.ac.kr

\begin{abstract}
This study investigated the prevalence of Listeria monocytogenes in slaughterhouses, and determined serovars and genotypes, and antibiotic resistance of the isolates obtained from slaughterhouses and humans in Korea. Two hundred ninety samples were collected from feces $(n=136)$, carcasses $[n=140$ (cattle: $n=61$, swine: $\mathrm{n}=79)$ ], and washing water $(\mathrm{n}=14)$ in nine slaughterhouses. Eleven human isolates were obtained from hospitals and the Korea Center for Disease Control and Prevention. Listeria monocytogenes was enriched and identified, using polymerase chain reaction (PCR) and 16S rRNA sequencing. Serovars and presence of virulence genes were determined, and genetic correlations among the isolates were evaluated by the restriction digest patterns of AscI. Antibiotic resistance of L. monocytogenes isolates were examined against 12 different antibiotics. Of 290 slaughterhouse samples, 15 (5.17\%) carcass samples were L. monocytogenes positive. Most L. monocytogenes isolates possessed all the virulence genes, while polymorphisms in the actA gene were found between carcass and human isolates. Serovars $1 / 2 \mathrm{a}(33.3 \%)$ and $1 / 2 \mathrm{~b}(46.7 \%)$ were the most frequent in carcass isolates. Genetic correlations among the isolates from carcass and clinical isolates were grouped within serotypes, but there were low geographical correlations. Most $L$. monocytogenes isolates were antibiotic resistant, and some strains showed resistance to more than four antibiotics. These results indicate that $L$. monocytogenes are isolated from carcass and human in Korea, and they showed high risk serotypes and antibiotic resistance. Therefore, intensive attentions are necessary to be aware for the risk of $L$. monocytogenes in Korea.
\end{abstract}

Keywords Listeria monocytogenes, slaughterhouse, epidemiological analysis, molecular typing, antibiotic

\section{Introduction}

Listeria monocytogenes is a Gram-positive zoonotic pathogen, responsible for

(C) Korean Society for Food Science of Animal Resources. This is an open access article distributed under the terms of the Creative Commons Attribution Non-Commercial License (http://creativecommons.org/licences/by-nc/3.0) which permits unrestricted non-commercial use, distribution, and reproduction in any medium, provided the original work is properly cited. 
listeriosis (Fagerlund et al., 2016; Pérez-Trallero et al., 2014). The pathogen is ubiquitous in the environment, and has been detected in water and soil as well as animal feces. Cross-contamination of carcasses can occur in slaughterhouses or meat processing plants, resulting in transmission to consumers, and it causes fatal illness, especially in the susceptible populations such as the elderly, pregnant women, and fetuses (Sofos and Geornaras, 2010). To treat listeriosis patients, ampicillin, gentamycin, or streptomycin are primarily used, but the resistance of L. monocytogenes has been increased to the antibiotics used for therapeutic purposes in human (Gerzova et al., 2015).

Meloni et al. (2013) investigated the prevalence of L. monocytogenes in swine carcasses in Italy from 2008 to 2011, and they reported that $33 \%$ of swine carcasses were L. monocytogenes positive with only two serotypes (1/2a and $1 / 2 \mathrm{c})$. Khen et al. (2015) investigated L. monocytogenes contamination in beef carcasses in the Republic of Ireland from July 2007 to June 2009 , and reported that $27 \%$ of bovine hide and $14 \%$ of pre-chill carcasses were contaminated with L. monocytogenes, and the most commonly isolated serotype groups were $1 / 2 \mathrm{a}$ and $4 \mathrm{~b}$. In the US, the prevalence of $L$. monocytogenes in cattle carcasses was $0 \%-23.2 \%$ depending on slaughterhouse and season (Guerini et al., 2007).

L. monocytogenes outbreaks in the US have recently been linked to consumption of packaged salad, soft cheese and cantaloupes, and the pathogen caused 292 deaths or fetal losses from 2009 to 2011, with a mortality rate of approximately $21 \%$ (CDC, 2013; CDC, 2016). In the EU member states, L. monocytogenes outbreaks were linked to the intake of ready-toeat meat and poultry, cheese and fishery products (EFSA, 2013a). In 2011, 0.32 cases per 10,000 individuals were reported in the EU member states (EFSA, 2007; EFSA, 2013b). In Japan, the first L. monocytogenes outbreak was reported in 2001, caused by consumption of contaminated cheese (Makino et al., 2005). The incidence rate in Japan was estimated to be 0.65 cases per million (83 cases per year), which is lower than that in the US and EU member states (Okutani et al., 2004). In Korea, L. monocytogenes is considered not threatening human because there are no reported L. monocytogenes outbreaks. However, L. monocytogenes has been isolated from various foods such as sausages, smoked duck, and smoked salmon in Korea. In addition, the statistics of HIRAS (2016) showed that the number of listeriosis cases has increased from 16 in 2012 to 33 in 2014. These results indicate that there should be serious attention on L. monocytogenes in Korea.

The antibiotics consumption through self-prescription by farmers for prevention and treatment of animal disease increased by $25 \%$ from 2003 to 2012 (Lim et al., 2014b). Since then, many studies reported the higher prevalence of antibiotic resistant Escherichia coli, Salmonella spp., Campylobacter spp. and Staphylococcus aureus in Korea (Chae et al., 2011; Lim et al., 2011; Lim et al., 2014a; Kim et al., 2011). Although L. monocytogenes rarely acquired antibiotic resistance, the first antibiotic resistant L. monocytogenes was found in 1988 (Altuntas et al., 2012), and recent studies reported the antibiotic resistances of L. monocytogenes to ampicillin, amoxicillin, gentamicin, chloramphenicol, erythromycin, tetracycline, and vancomycin (Chen et al., 2009; Ennaji et al., 2008; Pesavento et al., 2010; Yücel et al., 2005). However, there are only limited Korean studies on the prevalence of antibiotic resistant L. monocytogenes.

The objective of this study was to investigate the prevalence of L. monocytogenes in slaughterhouses and to determine serotype, genetic correlations, and antibiotic resistances of L. monocytogenes isolated from slaughterhouses and humans in Korea.

\section{Materials and Methods}

\section{Sample collection}

Samples were collected from nine slaughterhouses (four in central area, three in southeastern area, and two in southwestern 
area) in Korea. In each slaughterhouse, three swine farms and three cattle farms were randomly selected, and three carcasses from each farm were randomly selected for sampling. After evisceration, fecal samples $(n=136)$ were collected aseptically by cutting the cecum with a sterile scalpel, and these samples were placed in plastic vials. To obtain carcass samples ( $\mathrm{n}=140)$ which were identical carcasses for collected fecal samples, $10 \mathrm{~cm} \times 10 \mathrm{~cm}$ sections of the rump areas of carcasses were swabbed with sterile gauze pads rehydrated with $40 \mathrm{~mL}$ buffered peptone water (BPW; Becton, Dickinson and Company, Sparks, MD, USA). Fourteen samples of the water used to wash the carcass were collected in conical tubes as environment samples. All slaughterhouse samples were stored at cold temperature until analyzed. In addition, 11 human isolates of $L$. monocytogenes were obtained from hospitals and the Korean Centers for Disease Control and Prevention.

\section{L. monocytogenes isolation}

Carcass samples were homogenized with $50 \mathrm{~mL}$ Listeria enrichment broth (LEB; Becton, Dickinson and Company) in a pummeler (BagMixer ${ }^{\circledR} 400$, Interscience, Saint Nom, France). The homogenates, fecal (25 g) and water (10 mL) samples in $50 \mathrm{~mL}$ LEB were enriched at $30^{\circ} \mathrm{C}$ for $24 \mathrm{~h}$. For secondary enrichment, $1 \mathrm{~mL}$ aliquot of the primary enrichment were inoculated in $9 \mathrm{~mL}$ Fraser broth (Becton Dickinson and Company) supplemented with Fraser broth supplement (Becton, Dickinson and Company) and incubated at $37^{\circ} \mathrm{C}$ for $24-48 \mathrm{~h}$. A loopful aliquot of the secondary enrichments was streaked on a Palcam agar (Becton, Dickinson and Company), followed by incubation at $30^{\circ} \mathrm{C}$ for $48 \mathrm{~h}$. Presumptive L. monocytogenes colonies on the Palcam agar plates were inoculated in $10 \mathrm{~mL}$ tryptic soy broth plus $0.6 \%$ yeast extract (TSBYE; Becton, Dickinson and Company), followed by incubation at $30^{\circ} \mathrm{C}$ for $48 \mathrm{~h}$.

A loopful aliquot of the cultures was then streaked on brain-heart infusion (BHI) agar (Becton, Dickinson and Company) and incubated at $30^{\circ} \mathrm{C}$ for $24 \mathrm{~h}$. The isolated colonies on the plates were identified by polymerase chain reaction (PCR) analysis with prs (specific for Listeria spp.) primers [F (5' GCTGAAGAGATTGCGAAAGAAG 3') and R (5' CAAAGAAACCTTGGATTTGCGG 3')] (Doumith et al., 2004) and hlyA (specific for L. monocytogenes) primers [F (5'CCT AAC ATA TCC AGG TGC TCT C 3') and R (5' CTG ATT GCG CCG AAG TTT AC 3')] (Burall et al., 2011). PCR amplification was conducted using Phire Hot Start II DNA Polymerase Kit (Thermo Fisher, Waltham, MA, US) and performed by Rotor-Gene Q (Qiagen, Hilden, Germany). After an initial stage of $98^{\circ} \mathrm{C}$ for $30 \mathrm{sec}, 35 \mathrm{cycles}$ were performed with denaturation at $98^{\circ} \mathrm{C}$ for $5 \mathrm{sec}$, annealing at $60^{\circ} \mathrm{C}$ for $5 \mathrm{sec}$, and extension at $72^{\circ} \mathrm{C}$ for $10 \mathrm{sec}$. A final 1 -min extension was performed at $72^{\circ} \mathrm{C}$.

The hlyA-positive samples were further-analyzed by $16 \mathrm{~S}$ rRNA sequencing to identify L. monocytogenes. The primers $27 \mathrm{~F}$ (5' AGA GTT TGA TCM TGG CTC AG 3') and 1492R (5' TAC GGY TAC CTT GTT ACG ACT T 3') were used for the 16S rRNA sequencing PCR (Lane, 1991; Weisburg et al., 1991). The PCR reaction was performed with 20 ng genomic DNA as the template in a $30-\mu \mathrm{L}$ reaction mixture by using EF-Taq (Solgent, Daejeon, Korea). Activation of Taq polymerase was performed at $95^{\circ} \mathrm{C}$ for $2 \mathrm{~min}$, followed by 35 cycles of $95^{\circ} \mathrm{C}$ for $1 \mathrm{~min}, 55^{\circ} \mathrm{C}$ for $1 \mathrm{~min}$, and $72^{\circ} \mathrm{C}$ for $1 \mathrm{~min}$ and a final stage of $72^{\circ} \mathrm{C}$ for $10 \mathrm{~min}$. The amplified products were purified with a multiscreen filter plate (Millipore Corp., Bedford, MA, USA). The DNA samples containing the extension products were added to Hi-Di formamide (Applied Biosystems, Foster City, CA, USA); the mixture was incubated at $95^{\circ} \mathrm{C}$ for $5 \mathrm{~min}$ and on ice for $5 \mathrm{~min}$, and then analyzed using a ABI Prism 3730XL DNA analyzer (Applied Biosystems).

\section{Polymerase chain reaction (PCR) analysis of virulence factors}

Five virulence genes $(a c t \mathrm{~A}, i n l \mathrm{~A}, i n l \mathrm{~B}, p l c \mathrm{~B}$, and $h l y \mathrm{~A})$ were detected in isolated colonies from Palcam agar plates, using 
PCR analysis with the primers listed in Table 1. The colonies in Palcam agar plates were suspended in $50 \mu \mathrm{L}$ of $0.05 \mathrm{~N} \mathrm{NaOH}$ (Samchun, Gyeonggi, Korea) with $0.25 \%$ sodium dodecyl sulfate (SDS). One hundred microliters of sterile $\mathrm{dH}_{2} \mathrm{O}$ were added to the suspension, which was incubated at $99^{\circ} \mathrm{C}$ for $15 \mathrm{~min}$. For PCR amplification, this mixture $(2 \mu \mathrm{L})$ was mixed with Phire Hot Start II DNA Polymerase Kit (Thermo Fisher), mixed Taq DNA polymerase $\left(20 \mathrm{mM}\right.$ Tris-HCl, $\mathrm{pH} 7.4$ at $25^{\circ} \mathrm{C} ; 0.1 \mathrm{mM}$ EDTA; $1 \mathrm{mM} \mathrm{DTT;} 100 \mathrm{mM} \mathrm{KCl} ; 200 \mu \mathrm{g} / \mathrm{mL} \mathrm{BSA}$; and 50\% glycerol), $1 \times$ reaction buffer $[1.5 \mathrm{mM} \mathrm{MgCl}, 200 \mu \mathrm{M}$ deoxynucleoside triphosphates (dNTP; Promega Corporation, Madison, USA)], and $0.5 \mu \mathrm{M}$ each primer. PCR was performed by Rotor-Gene Q (Qiagen) with initial denaturation at $98^{\circ} \mathrm{C}$ for $30 \mathrm{sec}$, followed by 35 cycles of $98^{\circ} \mathrm{C}$ for $5 \mathrm{sec}, 60^{\circ} \mathrm{C}$ for 5 sec, and $72^{\circ} \mathrm{C}$ for $10 \mathrm{sec}$ and a final extension at $72^{\circ} \mathrm{C}$ for $1 \mathrm{~min}$. Twenty microliters of reaction PCR products were mixed with $4 \mu \mathrm{L}$ loading star (Dyne Bio, Gyeonggi, Korea), followed by electrophoresis analysis with a $1.5 \%$ agarose gel.

\section{L. monocytogenes serotyping}

Serotypes for L. monocytogenes isolates were determined by both agglutination and multiplex-PCR analysis. Common results for serotypes from both analyses were used as the serotypes for the isolates. For agglutination analysis, Listeria antisera (Denka Seiken, Tokyo, Japan) were used to identify O antigen and H antigen according to the manufacturer's instruction. Multiplex-PCR analysis was performed according to the previous methods with lmo0737, lmo1118, ORF2819, ORF2110, and prs gene target primers (Doumith et al., 2004). Amplification reactions for all isolates were performed using the Qiagen multiplex PCR kit (Qiagen) in Rotor-Gene Q with pre-incubation at $94^{\circ} \mathrm{C}$ for $15 \mathrm{~min}$, followed by 35 cycles at $94^{\circ} \mathrm{C}$ for $30 \mathrm{sec}, 57^{\circ} \mathrm{C}$ for $90 \mathrm{sec}$, and $72^{\circ} \mathrm{C}$ for $60 \mathrm{sec}$ and terminal elongation at $60^{\circ} \mathrm{C}$ for $30 \mathrm{~min}$. The final multiplex PCR products mixed with loading star were resolved on $1.5 \%$ agarose within $1 \times$ TAE buffer for 20 min. Subsequently, the serotypes of L. monocytogenes were determined by multiplex PCR amplification patterns.

\section{Pulsed-field gel electrophoresis}

L. monocytogenes isolates were analyzed using pulsed-field gel electrophoresis (PFGE) according to the standard protocol by Graves and Swaminathan (2001) with some modifications. L. monocytogenes cultures were embedded in $1 \%$ SeaKem gold agarose (Cambrex, NJ, USA) and lysed with cell lysis buffer (50 mM Tris, $50 \mathrm{mM}$ EDTA, 1\% Sarcosine) and proteinase $\mathrm{K}$ for $2 \mathrm{~h}$ at $54-55^{\circ} \mathrm{C}$. Molds of the samples were washed with TE buffer (10 mM Tris, $1 \mathrm{mM}$ EDTA, pH 8.0) for seven times, followed by digestion with restriction enzyme $A s c \mathrm{I}$ (Enzynomics, Korea) at $37^{\circ} \mathrm{C}$ for $2 \mathrm{~h}$. Size separation of restricted DNA fragments was performed in $0.5 \times$ Tris Borate EDTA (TBE) by using a CHEF MAPPER XA system (Bio-Rad, Richmond,

Table 1. Primers used for PCR amplification of virulence genes from Listeria monocytogenes isolates

\begin{tabular}{|c|c|c|c|}
\hline Primer & Size $(b p)$ & Sequence $\left(5^{\prime}\right.$ to $\left.3^{\prime}\right)$ & Reference \\
\hline inlA & 255 & $\begin{array}{l}\mathrm{F}: \text { CCTAGCAGGTCTAACCGCAC } \\
\mathrm{R}: \text { TCGCTAATTTGGTTATGCCC }\end{array}$ & Mathakiya et al., 2009 \\
\hline $\operatorname{in} l \mathrm{~B}$ & 146 & $\begin{array}{l}\mathrm{F}: \text { AAAGCACGATTTCATGGGAG } \\
\mathrm{R}: \text { ACATAGCCTTGTTTGGTCGG }\end{array}$ & Corantin et al., 2005 \\
\hline hly $\mathrm{A}$ & 174 & $\begin{array}{l}\mathrm{F}: \text { GCATCTGCATTCAATAAAGA } \\
\mathrm{R}: \text { TGTCACTGCATCTCCGTGGT }\end{array}$ & Wesley et al., 2002 \\
\hline $\operatorname{act} \mathrm{A}$ & $\begin{array}{l}268 \\
(385)\end{array}$ & $\begin{array}{l}\text { F : GACGAAAATCCCGAAGTGAA } \\
\text { R : CTAGCGAAGGTGCTGTTTCC }\end{array}$ & Jaradat et al., 2002 \\
\hline$p l c \mathrm{~B}$ & 261 & $\begin{array}{l}\mathrm{F}: \text { GGGAAATTTGACACAGCGTT } \\
\mathrm{R}: \text { ATTTTCGAAGGTAGTCCGCTTT }\end{array}$ & Corantin et al., 2005 \\
\hline
\end{tabular}

PCR, Polymerase chain reaction. 
CA, USA) with $1 \%$ SeaKem gold agarose gel at $14^{\circ} \mathrm{C}$ and $6.0 \mathrm{~V} / \mathrm{cm}$ angle of $120^{\circ}$ with a linear ramping factor of $2.2-54 \mathrm{sec}$ for 19 h. XbaI-digested Salmonella enterica-serotype Braenderup H9812 DNA was used as a standard to compare each band of L. monocytogenes isolates. After electrophoresis, the agarose gel was stained with SYBR gold (Molecular Probes, Eugene, USA) and destained with $\mathrm{dH}_{2} \mathrm{O}$ for $1 \mathrm{~h}$. Pattern images were captured using an LAS-3000 imaging system (Fujifilm, Japan), and PFGE patterns were analyzed using Gelcompar II 6.6 software (Applied Maths, Sint-Matins-Latem, Belgium). Similarity clustering analyses of all isolates were performed by UPGMA (unweighted pair group method with arithmetic mean) with Dice correlation coefficient and $1 \%$ tolerance.

\section{Antibiotic resistance analysis}

Antibiotic disc diffusion test was performed according to Clinical Laboratory Standards Institute procedure to evaluate antibiotic resistances (CLSI, 2014). A single isolated colony of L. monocytogenes was transferred into $10 \mathrm{~mL}$ TSBYE, incubated at $30^{\circ} \mathrm{C}$ for $24 \mathrm{~h}$. After the incubation, the culture was diluted with $5 \mathrm{~mL}$ phosphate buffered saline (PBS, pH 7.4; $\mathrm{KH}_{2} \mathrm{PO}_{4}, 0.2 \mathrm{~g} ; \mathrm{Na}_{2} \mathrm{HPO}_{4}, 1.5 \mathrm{~g} ; \mathrm{NaCl}, 8.0 \mathrm{~g} ; \mathrm{KCl}, 0.2 \mathrm{~g}$ in $1 \mathrm{~L}$ of $\mathrm{dH}_{2} \mathrm{O}$ ) to a turbidity equivalent to 0.2 at $\mathrm{OD}_{620}$ (approximately $10^{8} \mathrm{CFU} / \mathrm{mL}$ ). Sterile swab was dampened with the diluent, and spread onto the surface of a Muller-Hinton agar plate (MHA; Becton, Dickinson and Company). The MHA plates were dried at room temperature for 10 min to allow adsorption of the liquid. Antibiotic discs (Oxoid, Basingstoke, UK) were then placed on the surface of the MHA plates. The 12 antibiotics (amounts) were examined as following; gentamycin $(10 \mu \mathrm{g})$, penicillin G (10 units), tetracycline (30 $\mu \mathrm{g})$, spectinomycin $(100 \mu \mathrm{g})$, kanamycin $(30 \mu \mathrm{g})$, erythromycin $(15 \mu \mathrm{g})$, tigecycline $(15 \mu \mathrm{g})$, ampicillin $(10 \mu \mathrm{g})$, streptomycin $(10$ $\mu \mathrm{g})$, vancomycin $(30 \mu \mathrm{g})$, chloramphenicol $(30 \mu \mathrm{g})$, and rifampicin $(5 \mu \mathrm{g})(\mathrm{Oxoid})$. After incubation at $30^{\circ} \mathrm{C}$ for $24 \mathrm{~h}$, the diameters of the clear zones were measured and sensitivities (susceptible, intermediates, and resistance) were determined according to the standards of the Clinical Laboratory Standard Institute (CLSI, 2014).

\section{Results}

\section{Prevalence of L. monocytogenes}

Fifteen samples (5.17\%) of 290 samples such as carcasses, feces, and water samples from nine slaughterhouses were $L$. monocytogenes positive. The pathogen was isolated only from carcass samples, and not from fecal or water samples. Of 140 carcass samples, 15 samples (10.71\%) were contaminated with the pathogen, which could be considered high prevalence (Table 2). L. monocytogenes was isolated from six (66.7\%) of nine slaughterhouses (data not shown). Of 75 swine carcass samples, 11 samples (14.7\%) were contaminated with L. monocytogenes, and four (6.6\%) of 61 cattle carcass samples were contaminated with the pathogen (data not shown), indicating that the swine carcasses were more frequently contaminated with the pathogen than cattle carcasses in Korea.

\section{Serotypes of $L$. monocytogenes isolates}

Fifteen isolates from carcasses and 11 human isolates obtained from hospitals and KCDC in Korea were further analyzed for serotypes by multiplex PCR and agglutination assay. Multiplex PCR analysis classified L. monocytogenes isolates into four groups. Group 1 (1/2a and 3a), Group 2 (1/2c and 3c), Group $3(1 / 2 b, 3 b$, and 7), and Group 4 (4b, 4d, and 4e) of serovars as determined by lineage-specific and serogroup-specific sequences for L. monocytogenes strains according to the method by Doumith (2004). This method identified several serotypes rather than one serotype, and thus, an agglutination 
Table 2. Prevalence of Listeria monocytogenes in the slaughterhouse

\begin{tabular}{|c|c|c|c|c|}
\hline \multirow{2}{*}{ Slaughterhouse } & \multicolumn{3}{|c|}{ Sample } & \multirow{2}{*}{$\begin{array}{c}\text { Total } \\
(\%)\end{array}$} \\
\hline & Feces & Carcass (\%) & Environment & \\
\hline Central 1 & $0 / 18$ & $5 / 18(27.78)$ & $0 / 1$ & $5 / 37(13.51)$ \\
\hline Central 2 & $0 / 18$ & $1 / 18(5.56)$ & $0 / 2$ & $1 / 38(2.63)$ \\
\hline Central 3 & $0 / 18$ & $2 / 18(11.11)$ & $0 / 2$ & $2 / 38(5.26)$ \\
\hline Central 4 & $0 / 3$ & $0 / 6$ & 0 & $0 / 9$ \\
\hline South west 1 & $0 / 18$ & $4 / 18(22.22)$ & $0 / 2$ & $4 / 38(10.53)$ \\
\hline South west 2 & $0 / 18$ & $1 / 19(5.26)$ & $0 / 2$ & $1 / 39(2.56)$ \\
\hline South east 1 & $0 / 15$ & $2 / 15(13.33)$ & $0 / 2$ & $2 / 32(6.25)$ \\
\hline South east 2 & $0 / 19$ & $0 / 19$ & $0 / 2$ & $0 / 40$ \\
\hline South east 3 & $0 / 9$ & $0 / 9$ & $0 / 1$ & $0 / 19$ \\
\hline Total & $0 / 136$ & $15 / 140(10.71)$ & $0 / 14$ & $15 / 290(5.17)$ \\
\hline
\end{tabular}

assay was necessary; however, the result of agglutination assay could be affected by researcher subjectivity. Therefore, common serotypes identified in both methods were considered the serotypes of the isolate. The results showed that the human isolates were three $1 / 2 \mathrm{~b}$ isolates $(27.3 \%)$, three $4 \mathrm{~b}$ isolates $(27.3 \%)$, and two $1 / 2 \mathrm{a}$ isolates $(18.2 \%)$ (Table 3$)$, which are known to be the most common serotypes for foodborne disease (Althaus et al., 2014). While slaughterhouse isolates were five 1/2a isolates $(33.3 \%)$, seven $1 / 2 \mathrm{~b}$ isolates $(46.7 \%)$, and three $1 / 2 \mathrm{c}$ isolates $(20 \%)$ from cattle and swine carcasses (Table 4$)$. These results indicate that serotypes between slaughterhouse and human isolates are similar, and most strains were foodborne disease-related serotypes.

\section{Virulence characterization of $L$. monocytogenes}

Five virulence genes $(\operatorname{act} \mathrm{A}, \operatorname{inl} \mathrm{A}, \operatorname{in} l \mathrm{~B}, h l y \mathrm{~A}$, and $p l c \mathrm{~B})$ were observed for L. monocytogenes slaughterhouse and human isolates, except for inlB in L. monocytogenes SMFM-SI-15 (Fig. 1). The strain did not contain inlB, which is involved in

Table 3. Serotypes and information of Listeria monocytogenes isolates from humans

\begin{tabular}{lcc}
\hline Strains & Sources & Serotype \\
SMFM-CI-1 & Male, 18 year-old & $4 \mathrm{~b}$ \\
SMFM-CI-2 & Human, blood, 1/2a & $1 / 2 \mathrm{a}$ \\
SMFM-CI-3 & Female, blood, 82 year-old & $1 / 2 \mathrm{~b}$ \\
SMFM-CI-4 & Female, blood, 72 year-old & $1 / 2 \mathrm{~b}$ \\
SMFM-CI-5 & Male, blood, 67 year-old & $3 \mathrm{~b}$ \\
SMFM-CI-6 & Male, blood, 71 year-old & $1 / 2 \mathrm{~b}$ \\
SMFM-CI-7 & Male, blood, 73 year-old & $1 / 2 \mathrm{a}$ \\
SMFM-CI-8 & Male, stomach cancer, 66 year-old & $1 / 2 \mathrm{c}$ \\
SMFM-CI-9 & Female, bacterial meningitis, 61 year-old & $4 \mathrm{~d}$ \\
SMFM-CI-10 & Male, bacterial meningitis, 78 year-old & $4 \mathrm{~b}$ \\
SMFM-CI-11 & Female, hepatic abscess, 81 year-old & $4 \mathrm{~b}$ \\
\hline
\end{tabular}


Table 4. Serotypes and information of Listeria monocytogenes isolates from carcasses

\begin{tabular}{|c|c|c|c|}
\hline Strains & Sampling location ${ }^{1)}$ & Animal & Serotype \\
\hline SMFM-SI-2 & A & Swine & $1 / 2 b$ \\
\hline SMFM-SI-3 & A & Swine & $1 / 2 b$ \\
\hline SMFM-SI-4 & A & Swine & $1 / 2 b$ \\
\hline SMFM-SI-6 & $\mathrm{E}$ & Cattle & $1 / 2 \mathrm{a}$ \\
\hline SMFM-SI-7 & $\mathrm{E}$ & Cattle & $1 / 2 \mathrm{c}$ \\
\hline SMFM-SI-8 & $\mathrm{E}$ & Cattle & $1 / 2 \mathrm{c}$ \\
\hline SMFM-SI-9 & $\mathrm{E}$ & Cattle & $1 / 2 \mathrm{c}$ \\
\hline SMFM-SI-12 & $\mathrm{C}$ & Swine & $1 / 2 \mathrm{a}$ \\
\hline SMFM-SI-13 & $\mathrm{D}$ & Swine & $1 / 2 b$ \\
\hline SMFM-SI-14 & $\mathrm{D}$ & Swine & $1 / 2 b$ \\
\hline SMFM-SI-15 & $\mathrm{F}$ & Swine & $1 / 2 \mathrm{a}$ \\
\hline
\end{tabular}

1) A, slaughterhouse-1 in central area; B, slaughterhouse-2 in central area; C, slaughterhouse-3 in central area; D, slaughterhouse-1 in south west area; E, slaughterhouse-1 in south west area; F, slaughterhouse-2 in south west area.

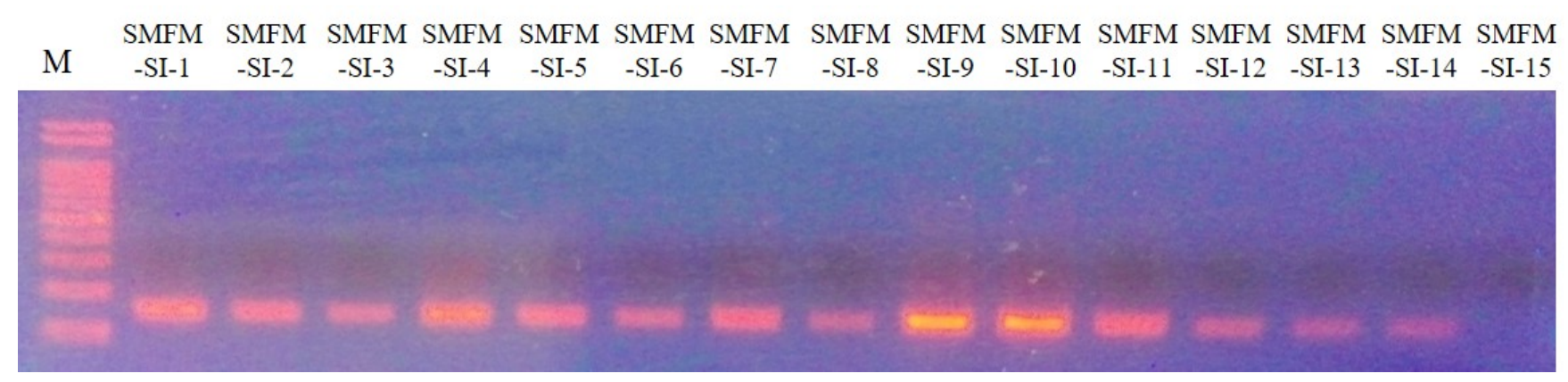

Fig. 1. PCR amplification of In/B from Listeria monocytogenes isolates (SI) obtained from carcasses. PCR amplification showed that $L$. monocytogenes isolate $\mathrm{SI}-15$ has no in/B, which plays a role in invasion.

mediating invasion into mammalian cells (Carvalho et al., 2014). Interestingly, 10 of 11 human isolates (90.9\%) had a 268-bp amplicon of actA, but most of 15 slaughterhouse isolates (86.7\%) had a 385-bp amplicon of actA (Fig. 2).

\section{PFGE genotype of $L$. monocytogenes isolates}

Twenty-six L. monocytogenes slaughterhouse and human isolates were genotyped using PFGE (Fig. 3). The application of DNA macro restriction with $A s c$ I revealed major four groups with $70 \%$ similarity and 12 clusters with $90 \%$ similarity. All $L$. monocytogenes isolates could be divided into two major patterns at approximately 55.3\% similarity, which were serotyped as $1 / 2 \mathrm{a}$ and $1 / 2 \mathrm{c}$ (59.3\% similarity between groups) and 1/2b-4 (64.7\% similarity). Group 1 (more than $80.4 \%$ similarity) included five isolates of serotype $1 / 2 \mathrm{c}(\mathrm{n}=4)$ and 1/2a. Group 2 included five isolates of serotype $1 / 2 \mathrm{a} ;$ L. monocytogenes SMFM-CI-2 human isolate had $93.3 \%$ similarity with L. monocytogenes strains SMFM-SI-6 (south west 1-swine) and 


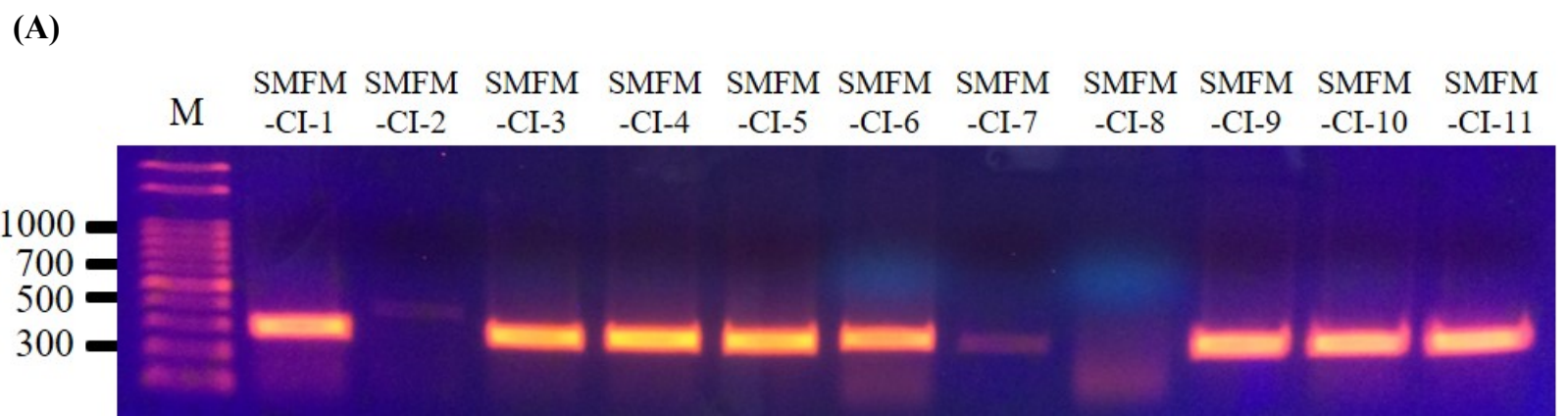

(B)

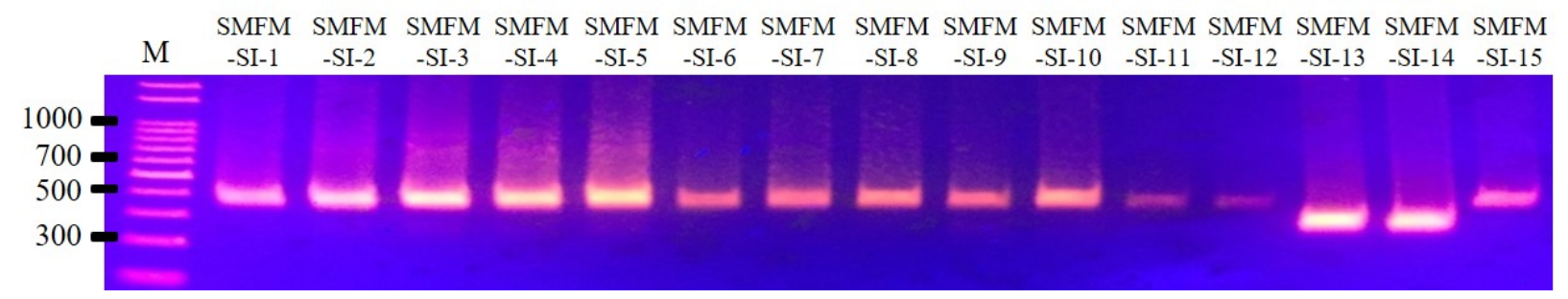

Fig. 2. PCR amplification of actA from Listeria monocytogenes isolates obtained from humans (A; CI) and carcasses (B; $\mathrm{SI}$ ). ActA gene showed generally different size of base pair between slaughterhouse and human isolates. $90.9 \%$ of human isolates had 268 bp size of actA, and $86.7 \%$ of slaughterhouse isolates had $385 \mathrm{bp}$.

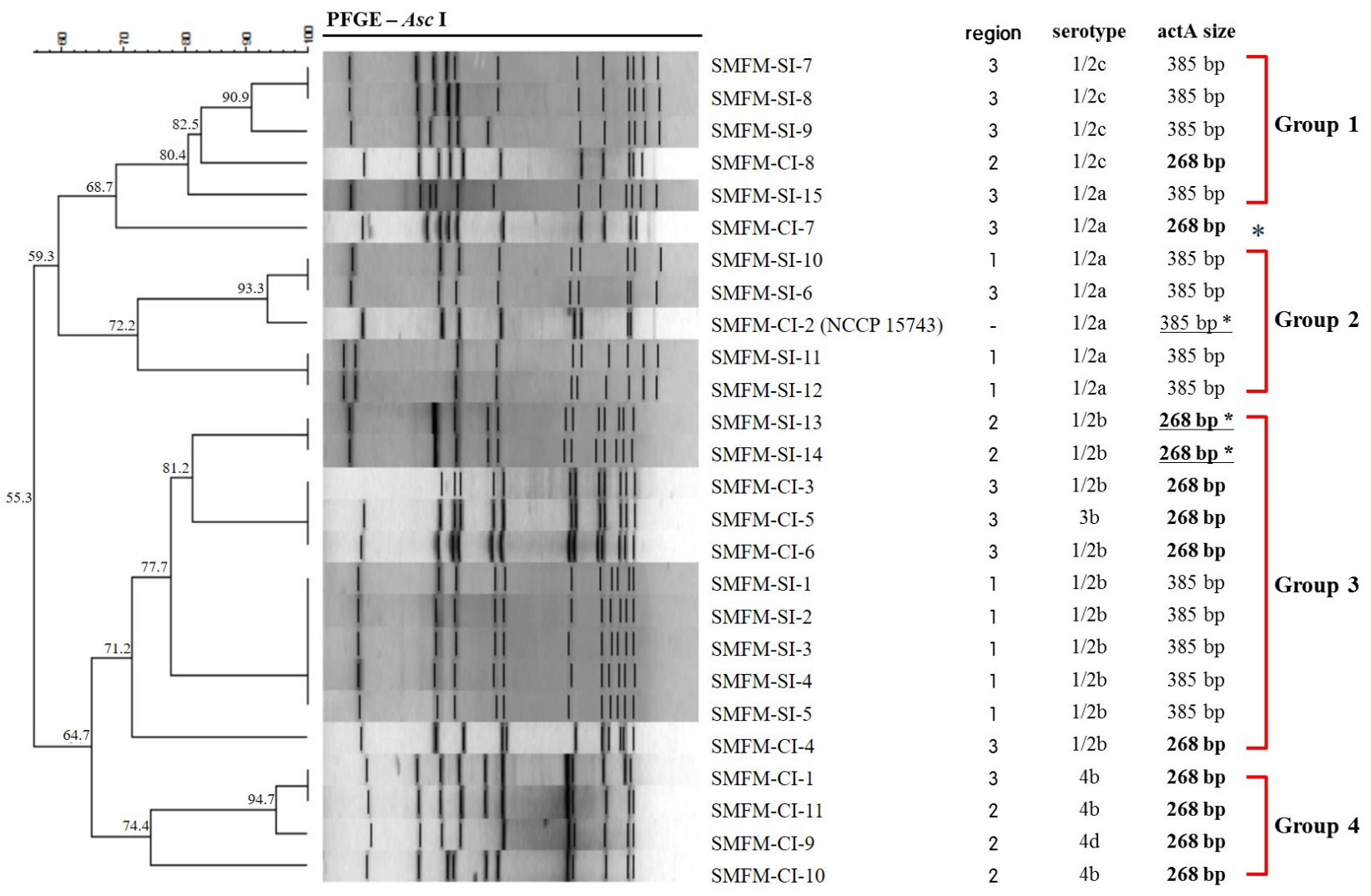

Fig. 3. PFGE patterns observed for Listeria monocytogenes isolates from carcasses and humans. Dendrogram (UPGMA clustering based on the Dice correlation coefficient) of L. monocytogenes Ascl PFGE patterns for 26 clinical and slaughterhouse isolates. Region 1: central area, Region 2: south west area, Region, 3: south east area. PFGE, pulsed-field gel electrophoresis; UPGMA, unweighted pair group method with arithmetic mean. 
SMFM-SI-10 (central 2-cattle). Group 3 included 11 isolates of serotype 1/2b $(n=10)$ and $3 b(n=1)$, which were divided into clusters based on actA size and geographical characterization. In Group 3, although isolation sources were different, the carcass isolates (L. monocytogenes strains SMFM-SI-13 and SMFM-SI-14) containing 268-bp actA showed more similarity (81.2\%) with human isolates containing 268-bp actA, than carcass isolates (77.7\%) with 385-bp actA. Group 4 contained serotype $4 \mathrm{~b}$ and $4 \mathrm{~d}$ isolates. Some L. monocytogenes isolates shared $100 \%$ similarity isolates from different locations.

\section{Antibiotic resistance}

All fifteen L. monocytogenes strains isolated from slaughterhouses were susceptible to the antibiotics, including gentamicin, bacitracin, spectinomycin, kanamycin, erythromycin, tigecycline, vancomycin, chloramphenicol, and rifampicin. However, the resistance rates of the isolates to penicillin G, tetracycline, ampicillin, and streptomycin resistances were 93.3\%, 20\%, 26.7\%, and 60\%, respectively (Table 5). L. monocytogenes strains SMFM-SI-13 and SMFM-SI-14 exhibited multiple resistances to four antibiotics such as tetracycline, penicillin, ampicillin, and streptomycin. L. monocytogenes SMFM-SI-12 also showed multiple resistance to penicillin G, ampicillin, and streptomycin. L. monocytogenes strains SMFMSI-1, SMFM-SI-5, and SMFM-SI-15 had resistance only penicillin G, L. monocytogenes SMFM-SI-11 had resistance to streptomycin, and L. monocytogenes SMFM-SI-8 had no resistance for used antibiotics in this study. In clinical isolates, all 11 L. monocytogenes strains isolated from clinical patients were susceptible to the antibiotics such as gentamycin, spectinomycin, kanamycin, tigecycline, and chloramphenicol (Table 6). Six L. monocytogenes isolates (54.5\%) from clinical patients had resistance more than three antibiotics, especially, two L. monocytogenes isolates (L. monocytogenes strains SMFM-CI-4 and SMFM-CI-7) showed multiple resistances to six antibiotics such as bacitracin, penicillin G, erythromycin, ampicillin, streptomycin, and rifampicin. These results indicate that clinical isolates had multiple antibiotic resistance more than the isolates from slaughterhouses.

\section{Discussion}

Although only a few cases of $L$. monocytogenes infection in humans are reported in Korea, it must be considered a major public health problem because of its ubiquitous distribution and presence in many animals, food products, raw materials, and environments. More information for the epidemiology, antibiotic resistant profiles and the genetic relationships of $L$. monocytogenes isolates from production chains would be helpful in understanding the cause of listeriosis and aspect of $L$. monocytogenes antibiotic resistance, and determining an appropriate approach for prevention of contamination.

In this study, 290 samples of carcasses, feces, and washing water from nine slaughterhouses in Korea were collected. Fifteen L. monocytogenes isolates were obtained, only from carcasses, not from feces and water samples. It suggests that pathogens on the carcasses may be cross-contaminated by workers or physical contact between carcasses in a slaughterhouse rather than cross-contamination from feces. This result was supported by a study of Muhterem-Uyar et al. (2015), suggesting that L. monocytogenes can be cross-contaminated onto meat carcasses from cutting board and packaging rooms due to unhygienic evisceration equipment. Thus, in our study it can be also suggested that $L$. monocytogenes on the carcasses might be from unhygienic environments.

Notably, at least $95 \%$ of $L$. monocytogenes strains isolated from listeriosis patients belonged to serotypes $1 / 2 \mathrm{a}, 1 / 2 \mathrm{~b}$, and $4 \mathrm{~b}$ (Kathariou, 2002). The most frequent L. monocytogenes serotypes in the carcasses were $1 / 2 \mathrm{a}$ and $1 / 2 \mathrm{~b}(80 \%)$, followed by $1 / 2$ c (20\%), which has low pathogenic potential but sporadically causes listeriosis in animals (Hadjilouka et al., 2014). This 
Table 5. Antibiotic sensitivity of Listeria monocytogenes strains isolated from slaughterhouses ( $\mathrm{n}=15$ )

\begin{tabular}{|c|c|c|c|c|c|c|c|c|c|c|c|c|c|c|c|c|c|c|}
\hline \multirow[b]{2}{*}{ Antibiotics } & \multicolumn{15}{|c|}{ Strains isolated from slaughterhouse } & \multicolumn{3}{|c|}{$\begin{array}{l}\text { Sensitivity of the isolates } \\
(\mathrm{n}, \%)^{1)}\end{array}$} \\
\hline & $\begin{array}{c}\text { SMF } \\
\text { M-SI- } \\
1\end{array}$ & $\begin{array}{c}\text { SMF } \\
\text { M-SI- } \\
2\end{array}$ & $\begin{array}{c}\text { SMF } \\
\text { M-SI- } \\
3\end{array}$ & $\begin{array}{c}\text { SMF } \\
\text { M-SI- } \\
4\end{array}$ & $\begin{array}{c}\text { SMF } \\
\text { M-SI- } \\
5\end{array}$ & $\begin{array}{c}\text { SMF } \\
\text { M-SI- } \\
6\end{array}$ & $\begin{array}{c}\text { SMF } \\
\text { M-SI- } \\
7\end{array}$ & $\begin{array}{c}\text { SMF } \\
\text { M-SI- } \\
8\end{array}$ & $\begin{array}{r}\text { SMF } \\
- \text { M-SI- } \\
9\end{array}$ & $\begin{array}{c}\text { SMF } \\
- \text { M-SI- } \\
10\end{array}$ & $\begin{array}{c}\text { SMF } \\
\text { M-SI- } \\
11\end{array}$ & $\begin{array}{c}\text { SMF } \\
\text { M-SI- } \\
12\end{array}$ & $\begin{array}{c}\text { SMF } \\
\text { M-SI- } \\
13\end{array}$ & $\begin{array}{c}\text { SMF } \\
\text { M-SI- } \\
14\end{array}$ & $\begin{array}{c}\text { SMF } \\
\text { M-SI- } \\
15\end{array}$ & $\begin{array}{l}\text { Suscep- } \\
\text { tible }\end{array}$ & $\begin{array}{l}\text { Inter- } \\
\text { mediate }\end{array}$ & $\begin{array}{c}\text { Resis- } \\
\text { tant }\end{array}$ \\
\hline Gentamycin & $\mathrm{S}$ & $\mathrm{S}$ & $\mathrm{S}$ & $\mathrm{S}$ & $\mathrm{S}$ & $\mathrm{S}$ & $\mathrm{S}$ & $\mathrm{S}$ & $\mathrm{S}$ & $\mathrm{S}$ & $\mathrm{S}$ & $\mathrm{S}$ & $\mathrm{S}$ & $\mathrm{S}$ & $\mathrm{S}$ & $\begin{array}{c}15 \\
(100)\end{array}$ & & \\
\hline Bacitracin & $\mathrm{S}$ & $\mathrm{S}$ & $\mathrm{S}$ & $\mathrm{S}$ & $\mathrm{S}$ & $\mathrm{S}$ & $\mathrm{S}$ & $\mathrm{S}$ & $\mathrm{S}$ & $\mathrm{S}$ & $\mathrm{S}$ & $\mathrm{S}$ & $\mathrm{S}$ & $\mathrm{S}$ & $\mathrm{S}$ & $\begin{array}{c}15 \\
(100)\end{array}$ & & \\
\hline Penicillin G & $\mathrm{R}$ & $\mathrm{R}$ & $\mathrm{R}$ & $\mathrm{R}$ & $\mathrm{R}$ & $\mathrm{R}$ & $\mathrm{R}$ & $\mathrm{S}$ & $\mathrm{R}$ & $\mathrm{R}$ & $\mathrm{R}$ & $\mathrm{R}$ & $\mathrm{R}$ & $\mathrm{R}$ & $\mathrm{R}$ & $\begin{array}{c}1 \\
(6.7)\end{array}$ & & $\begin{array}{c}14 \\
(93.3)\end{array}$ \\
\hline Tetracycline & $\mathrm{S}$ & $\mathrm{S}$ & $\mathrm{S}$ & $\mathrm{S}$ & $\mathrm{S}$ & $\mathrm{S}$ & $\mathrm{S}$ & $\mathrm{S}$ & $\mathrm{R}$ & $\mathrm{S}$ & $\mathrm{S}$ & $\mathrm{S}$ & $\mathrm{R}$ & $\mathrm{R}$ & $\mathrm{S}$ & $\begin{array}{c}12 \\
(80)\end{array}$ & & $\begin{array}{c}3 \\
(20)\end{array}$ \\
\hline $\begin{array}{l}\text { Spectino- } \\
\text { mycin }\end{array}$ & $\mathrm{S}$ & $\mathrm{S}$ & $\mathrm{S}$ & S & $\mathrm{S}$ & $\mathrm{S}$ & $\mathrm{S}$ & $\mathrm{S}$ & $\mathrm{S}$ & $\mathrm{S}$ & $\mathrm{S}$ & $\mathrm{S}$ & $\mathrm{S}$ & $\mathrm{S}$ & $\mathrm{S}$ & $\begin{array}{c}15 \\
(100)\end{array}$ & & \\
\hline Kanamycin & $\mathrm{S}$ & $\mathrm{S}$ & $\mathrm{S}$ & S & $\mathrm{S}$ & $\mathrm{S}$ & $\mathrm{S}$ & $\mathrm{S}$ & $\mathrm{S}$ & $\mathrm{S}$ & $\mathrm{S}$ & $\mathrm{S}$ & $\mathrm{S}$ & $\mathrm{S}$ & $\mathrm{S}$ & $\begin{array}{c}15 \\
(100)\end{array}$ & & \\
\hline $\begin{array}{l}\text { Erythro- } \\
\text { mycin }\end{array}$ & $\mathrm{S}$ & $\mathrm{S}$ & $\mathrm{S}$ & $\mathrm{S}$ & $\mathrm{S}$ & $\mathrm{S}$ & $\mathrm{S}$ & $\mathrm{S}$ & $\mathrm{S}$ & $\mathrm{S}$ & $\mathrm{S}$ & $\mathrm{S}$ & $\mathrm{S}$ & $\mathrm{S}$ & $\mathrm{S}$ & $\begin{array}{c}15 \\
(100)\end{array}$ & & \\
\hline Tigecycline & $\mathrm{S}$ & $\mathrm{S}$ & $\mathrm{S}$ & $\mathrm{S}$ & $\mathrm{S}$ & $\mathrm{S}$ & $\mathrm{S}$ & $\mathrm{S}$ & $\mathrm{S}$ & $\mathrm{S}$ & $\mathrm{S}$ & $\mathrm{S}$ & $\mathrm{S}$ & $\mathrm{S}$ & $\mathrm{S}$ & $\begin{array}{c}15 \\
(100)\end{array}$ & & \\
\hline Ampicillin & $\mathrm{S}$ & I & I & S & $\mathrm{S}$ & I & $\mathrm{S}$ & $\mathrm{S}$ & $\mathrm{S}$ & $\mathrm{R}$ & $\mathrm{S}$ & $\mathrm{R}$ & $\mathrm{R}$ & $\mathrm{R}$ & I & $\begin{array}{c}7 \\
(46.6)\end{array}$ & $\begin{array}{c}4 \\
(26.7)\end{array}$ & $\begin{array}{c}4 \\
(26.7)\end{array}$ \\
\hline $\begin{array}{l}\text { Strepto- } \\
\text { mycin }\end{array}$ & I & $\mathrm{R}$ & $\mathrm{R}$ & $\mathrm{R}$ & I & $\mathrm{R}$ & $\mathrm{R}$ & I & I & I & $\mathrm{R}$ & $\mathrm{R}$ & $\mathrm{R}$ & $\mathrm{R}$ & I & & $\begin{array}{c}6 \\
(40)\end{array}$ & $\begin{array}{c}9 \\
(60)\end{array}$ \\
\hline $\begin{array}{l}\text { Chloram- } \\
\text { phenicol }\end{array}$ & $\mathrm{S}$ & $\mathrm{S}$ & $\mathrm{S}$ & $\mathrm{S}$ & $\mathrm{S}$ & $\mathrm{S}$ & $\mathrm{S}$ & $\mathrm{S}$ & $\mathrm{S}$ & $\mathrm{S}$ & $\mathrm{S}$ & $\mathrm{S}$ & $\mathrm{S}$ & $\mathrm{S}$ & $\mathrm{S}$ & $\begin{array}{c}15 \\
(100)\end{array}$ & & \\
\hline Rifampicin & $\mathrm{S}$ & $\mathrm{S}$ & $\mathrm{S}$ & $\mathrm{S}$ & $\mathrm{S}$ & $\mathrm{S}$ & $\mathrm{S}$ & $\mathrm{S}$ & $\mathrm{S}$ & $\mathrm{S}$ & $\mathrm{S}$ & $\mathrm{S}$ & $\mathrm{S}$ & $\mathrm{S}$ & $\mathrm{S}$ & $\begin{array}{c}15 \\
(100)\end{array}$ & & \\
\hline $\begin{array}{l}\text { Susceptible } \\
(\mathrm{n}, \%)\end{array}$ & $\begin{array}{c}10 \\
(83.3)\end{array}$ & $\begin{array}{c}9 \\
(75)\end{array}$ & $\begin{array}{c}9 \\
(75)\end{array}$ & $\begin{array}{c}10 \\
(83.3)\end{array}$ & $\begin{array}{c}10 \\
(83.3)\end{array}$ & $\begin{array}{c}9 \\
(75)\end{array}$ & $\begin{array}{c}10 \\
(83.3)\end{array}$ & $\begin{array}{c}11 \\
(91.7)\end{array}$ & $\begin{array}{c}9 \\
(75)\end{array}$ & $\begin{array}{c}9 \\
(75)\end{array}$ & $\begin{array}{c}11 \\
(91.7)\end{array}$ & $\begin{array}{c}9 \\
(75)\end{array}$ & $\begin{array}{c}8 \\
(66.7)\end{array}$ & $\begin{array}{c}8 \\
(66.7)\end{array}$ & $\begin{array}{c}9 \\
(75)\end{array}$ & & & \\
\hline $\begin{array}{l}\text { Intermediate } \\
(\mathrm{n}, \%)\end{array}$ & $\begin{array}{c}1 \\
(8.3)\end{array}$ & $\begin{array}{c}1 \\
(8.3)\end{array}$ & $\begin{array}{c}1 \\
(8.3)\end{array}$ & 0 & $\begin{array}{c}1 \\
(8.3)\end{array}$ & $\begin{array}{c}1 \\
(8.3)\end{array}$ & 0 & $\begin{array}{c}1 \\
(8.3)\end{array}$ & $\begin{array}{c}1 \\
(8.3)\end{array}$ & $\begin{array}{c}1 \\
(8.3)\end{array}$ & 0 & 0 & 0 & 0 & $\begin{array}{c}2 \\
(16.7)\end{array}$ & & & \\
\hline $\begin{array}{l}\text { Resistant } \\
(\mathrm{n}, \%)\end{array}$ & $\begin{array}{c}1 \\
(8.3)\end{array}$ & $\begin{array}{c}2 \\
(16.7)\end{array}$ & $\begin{array}{c}2 \\
(16.7)\end{array}$ & $\begin{array}{c}2 \\
(16.7)\end{array}$ & $\begin{array}{c}1 \\
(8.3)\end{array}$ & $\begin{array}{c}2 \\
(16.7)\end{array}$ & $\begin{array}{c}2 \\
(16.7)\end{array}$ & 0 & $\begin{array}{c}2 \\
(16.7)\end{array}$ & $\begin{array}{c}2 \\
(16.7)\end{array}$ & $\begin{array}{c}1 \\
(8.3)\end{array}$ & $\begin{array}{c}3 \\
(25)\end{array}$ & $\begin{array}{c}4 \\
(33.3)\end{array}$ & $\begin{array}{c}4 \\
(33.3)\end{array}$ & $\begin{array}{c}1 \\
(8.3)\end{array}$ & & & \\
\hline
\end{tabular}

According to CLSI guidelines using the breakpoints of Staphylococcus species resistance because no resistance criteria exist for Listeria susceptibility testing in the CLSI guidelines (Byrne et al., 2016).

result indicates that $L$. monocytogenes serotypes $1 / 2 \mathrm{a}, 1 / 2 \mathrm{~b}$, and $4 \mathrm{~b}$ are the most prevalent isolates in carcasses and humans in Korea, which are the predominant serotypes causing human infections are 1/2a, 1/2b, and $4 \mathrm{~b}$ (Swaminathan and GernerSmidt, 2007). In this study, most isolates harbored virulence genes (act $\mathrm{A}, \operatorname{inl} \mathrm{A}$, inl $\mathrm{B}, h l y \mathrm{~A}$, and $p l c \mathrm{~B})$, indicating that they are pathogenic. Ten of the 11 clinical L. monocytogenes isolates showed $268 \mathrm{bp}$ size of act A, rather than $385 \mathrm{bp}$ size of actA which was the size of the gene in most of the slaughterhouse isolates. Jacquet el al. (2002) found that the low molecular mass of $\operatorname{act} \mathrm{A}$ was due to a deletion in $\operatorname{act} \mathrm{A}$, and it is probably not in the amino-terminal region, which is essential for F-actin assembly and movement. The deletion likely occurred in the internal proline-rich regions or carboxy-terminal domain (Sokolovic et al., 1996). Wiedmann et al. (1997) suggested that the length of actA is related to pathogenic properties. Ha et al. (2018) reported that the invasion efficiency of L. monocytogenes strains with the 268 bp size of actA was 1-2.5 times lower than those of the strains with the $385 \mathrm{bp}$ size of actA in healthy cells, but the invasion efficiency became similar in senescent 
Table 6. Antibiotic sensitivity of Listeria monocytogenes strains obtained from human $(\mathrm{n}=11)$

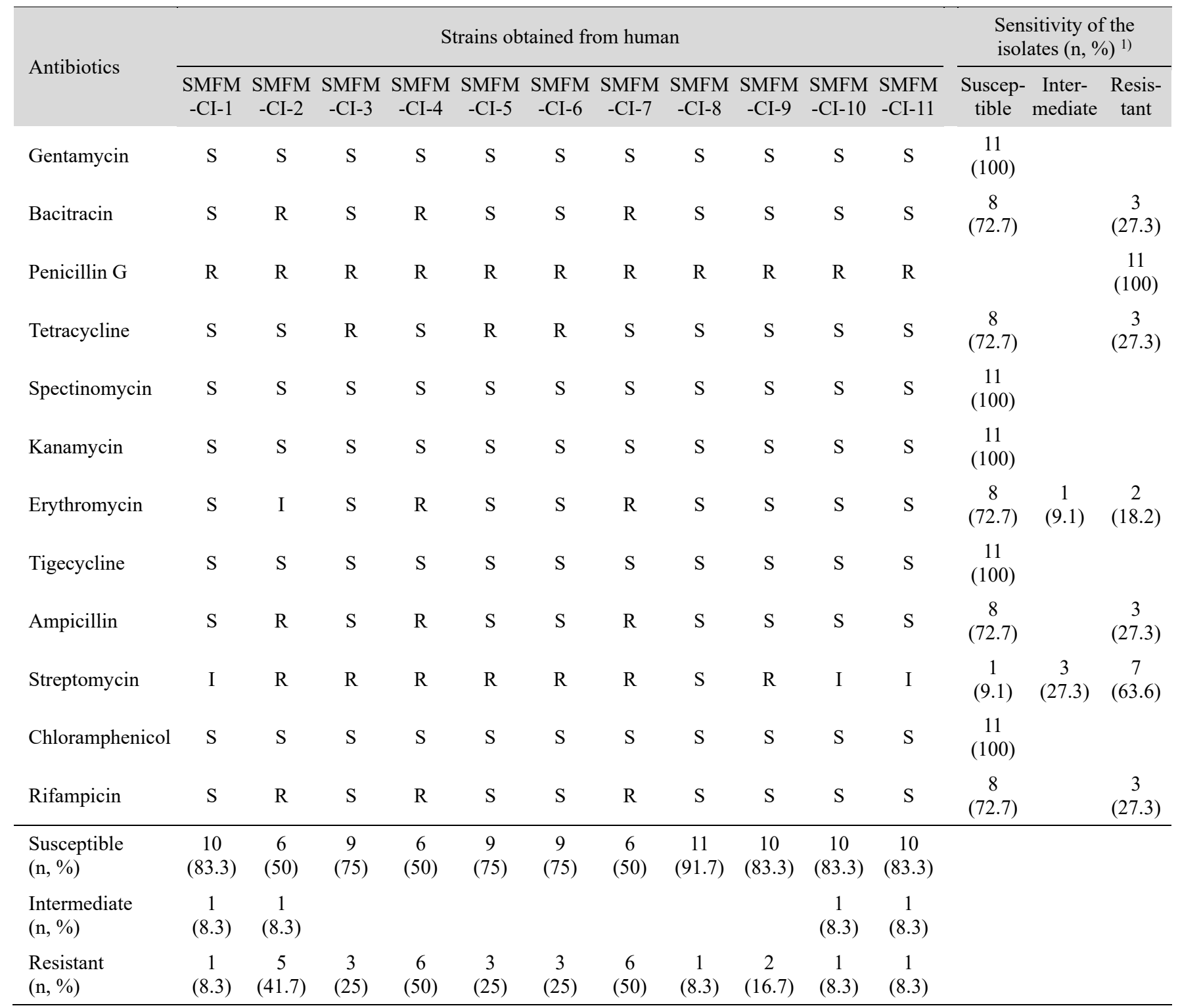

1) According to CLSI guidelines using the breakpoints of Staphylococcus species resistance because no resistance criteria exist for Listeria susceptibility testing in the CLSI guidelines (Byrne et al., 2016).

cells. Thus, this actA size may be related to pathogenicity.

PFGE of the DNA of the 26 isolates digested with AscI showed 7-16 fragments of approximately 30 to $1,130 \mathrm{~kb}$ (Neves et al., 2008). Generally, AscI and ApaI are considered the most useful restriction enzymes for Listeria spp. (Howard et al., 1992; Jang et al., 2005). However, Carriere et al. (1991) reported that the DNA of many Listeria serovar 1/2c isolates was not digested by ApaI and NotI. Therefore, we chose AscI as it is more efficient for serovar 1/2c and 4c (Brosch et al., 1994; Jang et al., 2006). When the DI value quoted by Simpson's discriminatory index was calculated (Hunter and Gaston, 1988), twenty six L. monocytogenes isolates from our study had 0.93 of DI. The isolates were divided into four groups with at least $70 \%$ similarity, and the serogroups clustered according to their pulsotypes: 1/2c (Group 1), 1/2a (Group 2), 1/2b (Group 3), and 4 types (Group 4). At the 0.90-1.00 similarity level, some clusters were diverse according to geographical origins and isolation origins. Thus, the results of PFGE indicates that L. monocytogenes serotypes are genetically correlated, and L. monocytogenes 
can be cross-contamination between different geographical locations, which may be caused by collecting animals from different farms but slaughtering in same slaughterhouse.

Although many foodborne pathogens were concerned because of their antibiotic resistance, the antibiotic resistance of $L$. monocytogenes has not been issued yet. To treat listeriosis various antibiotics such as penicillin, vancomycin, erythromycin, tetracycline, and chloramphenicol are currently used (Pesavento et al., 2010). Altuntas et al. (2012) reported that 7.1\% L. monocytogenes strain isolate from animal food showed antibiotic resistance to streptomycin. In our study, the $L$. monocytogenes isolates showed the resistances to some of the therapeutic antibiotics such as for penicillin G (93.3\%) and tetracycline (20\%) isolated from slaughterhouses. Also, L. monocytogenes isolates from clinical patients have the resistances to penicillin $\mathrm{G}(100 \%)$ and streptomycin $(63.6 \%)$. In addition, some isolates were multidrug resistant to more than three antibiotics. Twenty percent L. monocytogenes isolates from slaughterhouses and 54.5\% isolates from clinical patients showed multidrug resistant. These results suggest that the antibiotic resistances of L. monocytogenes have been increased, especially to therapeutic antibiotics of listeriosis treatment for human, and thus, L. monocytogenes infection may cause worse pathological results than the past (Conter et al., 2009; Morvan et al., 2010; Srinivasan et al., 2005).

In conclusion, L. monocytogenes were isolated from carcasses in slaughterhouses in Korea, and the pathogens may be cross-contaminated in slaughterhouses. There were also human listeriosis patients, and the serotypes of the isolates from carcasses and humans were the one related to the foodborne illness such as $1 / 2 \mathrm{a}, 1 / 2 \mathrm{~b}$ and $4 \mathrm{~b}$ serotypes. In addition, the prevalence of multiantibiotic resistant $L$. monocytogenes was high, especially in human isolates. These results suggest that the risk of $L$. monocytogenes could be considered high in Korea. Therefore, intensive attention and control plans for $L$. monocytogenes are necessary.

\section{Acknowledgments}

This research was supported by a grant (Z-1543081-2014-15-01) from the Animal and Plant Quarantine Agency in 20142015.

\section{References}

Althaus D, Lehner A, Brisse S, Maury M, Tasara T, Stephan R. 2014. Characterization of Listeria monocytogenes strains isolated during 2011-2013 from human infections in Switzerland. Foodborne Pathog Dis 11:753-758.

Altuntas EG, Kocan D, Cosansu S, Ayhan K, Juneja VK, Materon L. 2012. Antibiotic and bacteriocin sensitivity of Listeria monocytogenes strains isolated from different foods. Food Nutr Sci 3:363-368.

Brosch R, Chen J, Luchansky JB. 1994. Pulsed-field fingerprinting of listeriae: Identification of genomic divisions for Listeria monocytogenes and their correlation with serovar. Appl Environ Microbiol 60:2584-2592.

Burall LS, Simpson AC, Datta AR. 2011. Evaluation of a serotyping scheme using a combination of an antibody-based serogrouping method and a multiplex PCR assay for identifying the major serotypes of Listeria monocytogenes. J Food Prot 74:403-409.

Byrne VDV, Hofer E, Vallim DC, Almeida RCDC. 2016. Occurrence and antimicrobial resistance patterns of Listeria monocytogenes isolated from vegetables. Braz J Microbiol 47:438-443.

Carriere C, Allardet-Servent A, Bourg G, Audurier A, Ramuz M. 1991. DNA polymorphism in strains of Listeria monocytogenes. J Clin Microbiol 29:1351-1355. 
Carvalho F, Sousa S, Cabanes D. 2014. How Listeria monocytogenes organizes its surface for virulence. Front Cell Infect Microbiol 4:48.

Centers for Disease Control and Prevention (CDC). 2013. Vital signs: Listeria illnesses, deaths, and outbreaks-United States, 2009-2011. Available from: http://www.cdc.gov/mmwr/preview/mmwrhtml/mm6222a4.htm\#tab1. Accessed at April 4, 2016.

Centers for Disease Control and Prevention (CDC). 2016. Listeria outbreaks. Available from: http://www.cdc.gov/listeria/ outbreaks/index.html. Accessed at March 6, 2016.

Chae MH, Nam HM, Jang GC, Kim HJ, Kim SR, Jung SC, Kang DJ, Kim JK, Lim SK. 2011. Antimicrobial resistance in Campylobacter jejuni and Campylobacter coli isolated from food animals and raw meats in slaughterhouse in Korea during 2010. Kor J Vet Publ Hlth 35:239-245.

Chen J, Luo X, Jiang L, Jin P, Wei W, Liu D, Fang W. 2009. Molecular characteristics and virulence potential of Listeria monocytogenes isolates from Chinese food systems. Food Microbiol 26:103-111.

Clinical and Laboratory Standards Institute (CLSI). 2014. Performance standards for antimicrobial susceptibility testing; Twenty-fourth informational supplement (M100-S24).

Conter M, Paludi D, Zanardi E, Ghidini S, Vergara A, Ianieri A. 2009. Characterization of antimicrobial resistance of foodborne Listeria monocytogenes. Int J Food Microbiol 128:497-500.

Corantin H, Quessy S, Gaucher ML, Lessard L, Leblanc D, Houde A. 2005. Effectiveness of steam pasteurization in controlling microbiological hazards of cull cow carcasses in a commercial plant. Can J Vet Res 69:200-207.

Doumith M, Bucherieser C, Glaser P, Jaquet C, Martin P. 2004. Differentiation of the major Listeria monocytogenes serovars by multiplex PCR. J Clin Microbiol 42:3819-3822.

Ennaji H, Timinouni M, Ennaji MM, Hassar M, Cohen N. 2008. Characterization and antibiotic susceptibility of Listeria monocytogenes isolated from poultry and red meat in Morocco. Infect Drug Resist 1:45-50.

European Food Safety Authority (EFSA). 2007. The community summary report on trends and sources of zoonoses, zoonotic agents, antimicrobial resistance and foodborne outbreaks in the European Union in 2006. Available from: http://www. efsa.europa.eu/en/efsajournal/pub/130r. Accessed at March 27, 2016.

European Food Safety Authority (EFSA). 2013a. Analysis of the baseline survey on the prevalence of Listeria monocytogenes in certain ready-to-eat foods in the EU, 2010-2011 Part A: Listeria monocytogenes prevalence estimates. EFSA J 11:3241.

European Food Safety Authority (EFSA). 2013b. The European Union summary report on trends and sources of zoonoses, zoonotic agents and food-borne outbreaks in 2011. EFSA J 11:3129.

Fagerlund A, Langsrud S, Schirmer BCT, Møretrø T, Heir E. 2016. Genome analysis of Listeria monocytogenes sequence type 8 strains persisting in salmon and poultry processing environments and comparison with related strains. Plos One 11:e0151117.

Gerzova L, Babak V, Sedlar K, Faldynova M, Videnska P, Cejkova D, Jensen AN, Denis M, Kerouanton A, Ricci A, Cibin V, Österberg J, Rychlik I. 2015. Characterization of antibiotic resistance gene abundance and microbiota composition in feces of organic and conventional pigs from four EU countries. Plos One 10:e0132892.

Graves LM, Swaminathan B. 2001. PulseNet standardized protocol for subtyping Listeria monocytogenes by macrorestriction and pulsed-field gel electrophoresis. Int J Food Microbiol 65:55-62.

Guerini MN, Brichta-Harhay DM, Shackelford SD, Arthur TM, Bosilevac JM, Kalchayanand N, Wheeler TL, Koohmaraie 
M. 2007. Listeria prevalence and Listeria monocytogenes serovar diversity at cull cow and bull processing plants in the United States. J Food Prot 70:2578-2582.

Ha J, Oh H, Kim S, Lee J, Lee S, Lee H, Choi Y, Moon SS, Choi KH, Yoon Y. 2018. Effect of gene actA on the invasion efficiency of Listeria monocytogenes, as observed in healthy and senescent intestinal epithelial cells. J Microbiol Biotechnol 28:59-64.

Hadjilouka A, Andritsos ND, Paramithiotis S, Mataragas M, Drosinos EH. 2014. Listeria monocytogenes serotype prevalence and biodiversity in diverse food products. J Food Prot 77:2115-2120.

Health Insurance Review and Assessment Service (HIRAS). 2016. Disease statistics. Available from: http://opendata.hira. or.kr/op/opc/olap4thDsInfo.do. Accessed at April 4, 2016.

Howard PJ, Harsono KD, Luchansky JB. 1992. Differentiation of Listeria monocytogenes, Listeria innocua, Listeria ivanovii, and Listeria seeligeri by pulsed-field gel electrophoresis. Appl Environ Microbiol 58:709-712.

Hunter PR, Gaston MA. 1988. Numerical index of the discriminatory ability of typing systems: An application of Simpson's index of diversity. J Clin Microbiol 26:2465-2466.

Jacquet C, Gouin E, Jeannel D, Cossart P, Rocourt J. 2002. Expression of actA, ami, inlB, and listeriolysin O in Listeria monocytogenes of human and food origin. Appl Environ Microbiol 68:616-622.

Jang SS, Choo E, Han K, Miyamoto T, Heu S, Ryu S. 2006. Antibiotic resistance and genetic diversity of Listeria monocytogenes isolated from chicken carcasses in Korea. J Microbiol Biotechnol 16:1276-1284.

Jang SS, Fleet GH, Cox JM. 2005. Pulsed-field gel electrophoresis for subtyping of Listeria monocytogenes. J Korean Soc Appl Biol Chem 48:58-64.

Jaradat ZW, Schutze GE, Bhunia AK. 2002. Genetic homogeneity among Listeria monocytogenes strains from infected patients and meat products from two geographic locations determined by phenotyping, ribotyping and PCR analysis of virulence genes. Int J Food Microbiol 76:1-10.

Kathariou S. 2002. Listeria monocytogenes virulence and pathogenicity, a food safety perspective. J Food Prot 65:1811-1829.

Khen BK, Lynch OA, Carroll J, McDowell DA, Duffy G. 2015. Occurrence, antibiotic resistance and molecular characterization of Listeria monocytogenes in the beef chain in the republic of Ireland. Zoonoses Public Hlth 62:11-17.

Kim SR, Nam HM, Jang GC, Kim AR, Kang MS, Chae MH, Jung SC, Kang DJ, Kim JK, Lim SK. 2011. Antimicrobial resistance in Salmonella isolates from food animals and raw meats in Korea during 2010. Kor J Vet Publ Hlth 35:246254.

Lane DJ. 1991. 16S/23S rRNA sequencing. In Nucleic acid techniques in bacterial systematics. Stackebrandt E, Goodfellow M (ed). John Wiley and Sons, Chichester, UK. pp 115-175.

Lim SK, Byun JR, Lee HS, Moon DC, Jang GC, Jung SC. 2014a. Antimicrobial resistance of Escherichia coli strains isolated from pigs and their farm environment in Korea. Prev Vet Med 38:61-68.

Lim SK, Lee JE, Lee HS, Nam HM, Moon DC, Jang GC, Park YJ, Jung YG, Jung SC, Wee SH. 2014b. Trends in antimicrobial sales for livestock and fisheries in Korea during 2003-2012. Korean J Vet Res 54:81-86.

Lim SK, Nam HM, Jang GC, Kim SR, Chae MH, Jung SC, Kang DJ, Kim JK. 2011. Antimicrobial resistance in Staphylococcus aureus isolated from raw meats in slaughterhouse in Korea during 2010. Kor J Vet Publ Hlth 35:231-238.

Makino SI, Kawamoto K, Takeshi K, Okada Y, Yamasaki M, Yamamoto S, Igimi S. 2005. An outbreak of food-borne listeriosis due to cheese in Japan, during 2001. Int J Food Microbiol 104:189-196.

Mathakiya RA, Roy A, Nandasana KN, Koringa PG, Joshi CG. 2009. Evaluation of a rapid molecular method for detection of 
Listeria monocytogenes directly from broth culture. Vet World 2:177-178.

Meloni D, Piras F, Mureddu A, Fois F, Consolati SG, Lamon S, Mazzette R. 2013. Listeria monocytogenes in five Sardinian swine slaughterhouses: Prevalence, serotype, and genotype characterization. J Food Prot 76:1863-1867.

Morvan A, Moubareck C, Leclercq A, Hervé-Bazin M, Bremont S, Lecuit M, Courvalin P, Monnier AL. 2010. Antimicrobial resistance of Listeria monocytogenes strains isolated from humans in France. Antimicrob Agents Chemother 54:27282731.

Muhterem-Uyar M, Dalmasso M, Bolocan AS, Hernandez M, Kapetanakou AE, Kuchta T, Manios SG, Melero B, Minarovicova J, Nicolau AI, Rovira J, Skandamis PN, Jordan K, Rodriguez-Lazaro D, Stessl B, Wagner M. 2015. Environmental sampling for Listeria monocytogenes control in food processing facilities reveals three contamination scenarios. Food Control 51:94-107.

Neves E, Lourenco A, Silva AC, Coutingo R, Brito L. 2008. Pulsed-field gel electrophoresis (PFGE) analysis of Listeria monocytogenes isolates from different sources and geographical origins and representative of the twelve serovars. Syst Appl Microbiol 31:387-392.

Okutani A, Okada Y, Yamamoto S, Igimi S. 2004. Nationwide survey of human Listeria monocytogenes infection in Japan. Epidemiol Infect 132:769-772.

Pérez-Trallero E, Zigorraga C, Artieda J, Alkorta M, Marimón JM. 2014. Two outbreaks of Listeria monocytogenes infection, Northern Spain. Emerg Infect Dis 20:2155-2157.

Pesavento G, Ducci B, Nieri D, Comodo N, Nostro AL. 2010. Prevalence and antibiotic susceptibility of Listeria spp. isolated from raw meat and retail foods. Food Control 21:708-713.

Sofos JN, Geornaras I. 2010. Overview of current meat hygiene and safety risks and summary of recent studies on biofilms, and control of Esherichia coli O157:H7 in nonintact, and Listeria monocytogenes in ready-to-eat, meat products. Meat Sci 86:2-14.

Sokolovic Z, Schüller S, Bohne J, Baur A, Rdest U, Dickneite C, Nichterlein T, Goebel W. 1996. Differences in virulence and in expression of PrfA and PrfA-regulated virulence genes of Listeria monocytogenes strains belonging to serogroup 4. Infect Immun 64:4008-4019.

Srinivasan V, Nam HM, Nguyen LT, Tamilselvam B, Murinda SE, Oliver SP. 2005. Prevalence of antimicrobial resistance genes in Listeria monocytogenes isolated from dairy farms. Foodborne Pathog Dis 2:201-211.

Swaminathan B, Gerner-Smidt P. 2007. The epidemiology of human listeriosis. Microbes Infect 9:1236-1243.

Weisburg WG, Barns SM, Pelletier DA, Lane DJ. 1991. 16S Ribosomal DNA amplification for phylogenetic study. J Bacteriol 173:697-703.

Wesley IV, Harmon KM, Dickson JS, Schwartz AR. 2002. Application of a multiplex polymerase chain reaction assay for the simultaneous confirmation of Listeria monocytogenes and other Listeria species in turkey sample surveillance. J Food Prot 65:780-785.

Wiedmann M, Bruce JL, Keating C, Johnson AE, McDonough PL, Batt CA. 1997. Ribotypes and virulence gene polymorphisms suggest three distinct Listeria monocytogenes lineages with differences in pathogenic potential. Infect Immun 65:2707-2716.

Yücel N, Çitak S, Önder M. 2005. Prevalence and antibiotic resistance of Listeria species in meat products in Ankara, Turkey. Food Microbiol 22:241-245. 